\title{
PENGARUH EFIKASI DIRI BERWIRAUSAHA TERHADAP NIAT BERWIRAUSAHA MASYARAKAT DESA
}

\author{
Ahmad Sya Roni \\ Universitas Negeri Surabaya \\ ahmadroni@mhs.unesa.ac.id \\ Sanaji \\ Universitas Negeri Surabaya \\ sanaji@unesa.ac.id
}

\begin{abstract}
Sidoarjo is a district with the most number of small and medium businesses in Indonesia, there reach 171,264 business units. The details, micro-business 154,891 units, small and medium businesses 154 units, and large businesses 16,000 units. One of the industrial centers in the city of Sidoarjo is the Tanggulangin leather craft industry. Most of the people of Kedensari village have the expertise and skills to create a product that can be marketed and has a high selling value. The purpose of this study was to examine and analyze the entrepreneurial self-efficacy towards the entrepreneurial intentions of the Kedensari village community, Tanggulangin subdistrict, Sidoarjo. This research is causality research with a quantitative approach. The sample collection technique uses 100 samples saturated with the number of respondents in a citizen of Kedensari. The research method is using a simple linear regression with the use of the SPSS 23 program for windows. Whereas, hypothesis testing using $t$-test showed that self-efficacy partially has a significant influence on interest entrepreneurship.
\end{abstract}

Keywords: entrepreneurial intentions; entrepreneurial self-efficacy; SMEs.

\section{PENDAHULUAN}

Indonesia masih menjadi negera berkembang ditandai dengan kondisi masyarakat yang memiliki pendapatan perkapita rendah, kebanyakan penduduknya miskin, tekonologi belum menjamah ke daerah-daerah pelosok serta masih banyaknya jumlah pengangguran. Pengangguran terjadi karena perbandingan pencari pekerjaan yang terlalu banyak di segala level pendidikan mulai dari tingkat SMP sampai dengan perguruan tinggi tidak sebanding dengan pekerjaan yang tersedia, sehingga masih banyak terdapat pengangguran (Yunita, 2014).

Ada dua solusi mengatasi pengangguran yang dapat dilakukan oleh pemerintah. Pemerintah dapat mengatasi pengangguran secara langsung dan tidak langsung. Dalam mengatasi penganguran secara langsung pemerintah bisa menciptakan lapangan pekerjaan sebanyak-banyaknya dengan merata, sedangkan dalam mengatasi pengangguran secara tidak langsung pemerintah perlu membekali pengetahuan, keterampilan dan sikap kewirausahaan pada para pencari kerja melalui pengembangan kewirausahaan (Sari, 2018).

Wirausaha memiliki pengaruh yang besar dalam membangun mental masyarakat Indonesia, menambah lapangan pekerjaan, mengatasi pengangguran, dan memperkuat ekonomi Indonesia. Satu wirausaha akan melahirkan wirausaha yang lain, semakin banyak wirausaha maka semakin banyak pula lapangan pekerjaan sehingga pengangguran akan teratasi dengan banyaknya lapangan pekerjaan yang tercipta oleh wirausaha, jumlah wirausaha di Indonesia masih tergolong rendah, saat ini rasio wirausahawan dalam negeri masih sekitar 3,1\% dari total populasi penduduk sebesar 265 juta jiwa atau sekitar 8,06 juta orang yang berwirausaha. Angka tersebut sangat kecil jika dibandingkan dengan Singapura yang mencapai $7 \%$ serta Cina dan Jepang yang sudah di atas 10 persen, meskipun rasio tersebut sudah melampaui standar internasional, yakni $2 \%$ (Hartarto, 2018).

Sekitar 99,9 persen dari total jumlah pelaku usaha nasional pelaku UMKM yang jumlahnya kurang lebih 57,9 juta. Dalam lima tahun terakhir, sektor UMKM berkontribusi terhadap kesempatan kerja mencapai 97 persen atau 107,7 juta orang. Karena itulah dibutuhkan solusi tepat untuk mengurangi jumlah pengangguran. Salah satunya yaitu dengan mendorong laju pertumbuhan usaha kecil menengah 
Ahmad Sya Roni \& Sanaji. Pengaruh Efikasi Diri Berwirausaha terhadap Niat Berwirausaha Masyarakat Desa

di seluruh penjuru Indonesia. UMKM punya peran strategis dalam memerangi kemiskinan dan pengangguran. kekuatan sektor UMKM sudah terbukti tatkala Indonesia mengalami krisis keuangan pada 1997-1998. Hanya sektor UMKM yang masih tumbuh, bahkan pasca krisis ekonomi jumlah UMKM tidak berkurang, justru terus meningkat. Dari hasil data survei Badan Ekonomi Kreatif (BEKRAF) dengan Badan Pusat Statistik (2016) bahwa industri ekonomi kreatif di Indonesia pada 2015 lalu tercatat menyumbangkan Rp 852 triliun kepada pendapatan domestik bruto (PDB) nasional, dan di tahun 2016 tercatat naik mencapai Rp 922,58 triliun dengan nilai kontribusi terhadap PDB nasional sebesar 7,44 persen.UKM merupakan representasi ekonomi rakyat dikarenakan dapat menyerap tenaga kerja $\pm 90 \%$ serta memberikan kontribusi sebesar $58 \%$ pada Produk Domestik Bruto Nasional (Kusumaningrum, 2018).

Kabupaten Sidoarjo merupakan kabupaten dengan usaha kecil menengah terbanyak di Indonesia. Total Usaha Mikro Kecil Menengah (UMKM) di sana mencapai 171.264 unit usaha. Rinciannya, usaha mikro 154.891 unit, usaha kecil menengah 154 unit, dan usaha besar 16.000 unit (Kartika, 2017). Salah satu sentra industri yang ada di Kota Sidoarjo adalah sentra industri kerajinan kulit Tanggulangin, tepatnya berlokasi di desa Kedensari kecamatan Tanggulangin, dari hasil observasi, sebagian besar penduduk desa Kedensari mayoritas mata pencahariannya adalah pengrajin, yang menjadikan desa Kedensari dikenal sebagai sentra industri kerajinan khususnya produk tas, koper, dompet dan lainnya. Namun sangat disayangkan, dari sekian banyak pengrajin dan penduduk yang memiliki keahlian serta memiliki pengalaman untuk menciptakan suatu produk layak jual, sebagian besar dari mereka hanyalah sebagai pekerja dan pencari kerja (job seeker), kurang adanya pencipta kerja (job creator). Apabila sekian banyak dari mereka menjadi wirausahawan, maka jumlah wirausahawan di desa Kedensari akan meningkat dan dapat berkontribusi menambah jumlah lapangan pekerjaan baru yang akan berdampak pada berkurangnya pengangguran di desa Kedensari dan sekitarnya.

Pelaku kewirausahaan tidak hanya dimiliki oleh para wiraswasta kaya, namun kepada setiap orang yang mempunyai kemauan keras dan memiiki optimis serta kreatifitas misalnya, petani, karayawan, guru, dan lain sebagainya (Firmansyah, 2013). Keyakinan akan kemampuan yang dimiliki untuk berwirausaha sering disebut sebagai entrepreneurial self-efficacy (ESE). Menurut Mc. Gee et. al. (2009) entrepreneurial self-efficacy adalah suatu konstruk yang mengukur kepercayaan individu pada kemampuan yang dimiliki dalam berkecimpung dalam dunia kewirausahaan.

Penelitian ini bertujuan menguji hubungan Efikasi Diri Berwirausaha dengan niat berwirausaha pada masyarakat desa Kendensari Tanggulangin Sidoarjo sebagai salah desa yang masuk dalam kawasan sentra industri tas dan koper di Sidoarjo.

\section{KAJIAN PUSTAKA DAN PENGEMBANGAN HIPOTESIS}

\section{Efikasi Diri Berwirausaha}

Entrepreneurial self-efficacy adalah suatu konstruk yang mengukur kepercayaan individu pada kemampuan yang dimiliki dalam berkecimpung dalam dunia kewirausahaan (McGee, 2009). Terdapat 5 indikator efikasi diri berwirausaha, yakni searching, artinya proses pencarian sebuah gagasan dan informasi yang dibutuhkan untuk memulai kegiatan usaha. Kedua adalah planning merupakan merencanakan atau menentukan visi, misi dan tujuan, strategi, kebijakan, prosedur, aturan, program dan anggaran yang diperlukan untuk menjalankan suatu usaha atau bisnis tertentu. Ketiga yakni marshaling, yaitu kepercayaan diri seseorang untuk menyusun atau mengatur suatu organisasi dengan melibatkan orang lain untuk mendiskusikan masalah yang terjadi. Keempat implementing-people, yaitu kemampuan yang dimiliki seseorang untuk mengatur seorang atau sekelompok orang di dalam sebuah organisasi. Kelima, implementing-financial, yaitu kemampuan yang dimiliki dalam mengelola keuangan pribadi maupun organisasi (Mc Gee et al., 2009).

\section{Niat Berwirausaha}

Menurut Yanto dalam Suryaman (2006:22), niat wirausaha adalah kemampuan untuk memberanikan diri dalam memenuhi kebutuhan hidup serta memecahkan permasalahan hidup, memajukan usaha atau menciptakan usaha baru dengan kekuatan yang ada pada diri sendiri. Terdapat 3 indikator niat 
berwirausaha, yaitu perasaan tertarik untuk berwirausaha, karir berwirausaha, dan berniat untuk direalisakan di masa yang akan datang.

\section{Hubungan antar Variabel}

Menurut José Luis (2011) efikasi diri berwirausaha (ESE) dianggap kemampuan yang dapat mengubah keyakinan seseorang pada dirinya untuk menyelesaikan tugas-tugas yang diperlukan untuk berhasil memulai dan membangun usaha baru. Lebih spesifik lagi, efikasi diri berwirausaha didefinisikan sebagai tingkat di mana seseorang percaya bahwa dia mampu berhasil memulai usaha bisnis baru. Bandura (2012) meyakini bahwa efikasi diri berwirausaha memengaruhi motivasi dan kompetensi mereka untuk memasuki proses yang menantang untuk memulai bisnis mereka sendiri dan menunjukkan sejauh mana persiapan akademis mereka untuk jalur karier masa depan mereka sebagai wirausaha.

Niat merupakan prediktor yang kuat dari suatu tindakan. Individu yang memiliki niat berwirausaha, lebih memiliki kesiapan dibandingkan individu yang belum memilikinya. Niat berwirausaha dapat menjadi tolak ukur dari suatu tindakan individu, apakah individu tersebut akan berkarir menjadi wirausaha atau bukan wirausaha (Ajzen, 2008). Efikasi diri berwirausaha adalah keyakinan pada kemampuan yang dimiliki oleh seseorang dalam menciptakan bisnis. Seseorang yang memiliki efikasi diri tinggi dalam hal kewirausahaan akan memiliki niat yang kuat untuk berwirausaha, begitu pula sebaliknya (Artiandewi, 2016).

H1: Diduga efikasi diri berwirausaha berpengaruh positif dan signifikan terhadap niat berwirausaha masyarakat desa Kedensari, kecamatan Tanggulangin - Sidoarjo.

\section{METODE PENELITIAN}

Jenis penelitian yang digunakan dalam penelitian ini adalah kuantitatif. Penelitian ini dilakukan di Desa Kedensari, Kecamatan Tanggulangin, Kabupaten Sidoarjo. Populasi yang dimaksud dalam penelitian ini adalah masyarakat desa Kedensari, kecamatan Tanggulangin - Sidoarjo yang mempunyai karakteristik sebagai berikut: Responden dalam penelitian ini adalah penduduk desa Kedensari, berusia minimal 16 tahun dengan asumsi telah mampu untuk memahami dan mengisi angket dan responden memiliki rencana untuk berwirausaha. Teknik pengambilan sampel yang digunakan adalah penelitian ini adalah nonprobability sampling dengan metode pengambilan sampel purposive sampling dan penarikan jumlah sampel menggunakan rumus Slovin. Rentang sampel yang dapat diambil dari teknik Slovin adalah antara 10-20\% dari populasi penelitian. Jumlah populasi dalam penelitian ini adalah sebanyak 1.086 orang, sehingga presentase kelonggaran yang digunakan adalah $10 \%$ dan hasil perhitungan dapat dibulatkan untuk mencapai kesesuaian. Penghitungan untuk mengetahui sampel penelitian dapat dilihat di rumus (1). $n=91,6$; disesuaikan menjadi 100 responden. Sampel yang mejadi responden dalam penelitian ini di sesuaikan menjadi sebanyak 100 orang atau sekitar 9,2\% dari seluruh target populasi.

$n=\frac{1086}{1+1086(0,1)^{2}} n=\frac{1086}{11,86} n=91,6$

Teknik pengumpulan data dalam penelitian ini yaitu dengan menggunakan kuisioner metode angket dengan skala likert 5, dan metode wawancara penelitian dengan target sampel. Penggunaan skala ini dipilih untuk melihat seberapa kuat subjek penelitian akan setuju atau tidak setuju dengan menggunakan skala 5 titik. Variabel efikasi diri berwirausaha diukur menggunakan 5 dimensi. Secara spesifik, lima dimensi ESE (Entrepreneurial Self-Efficacy) diidentifikasi dan diberi label searching, planning, marshalling, implementing-people, dan implementing-financial yang merujuk kepada Mc Gee et. al. (2009). Adapun variabel niat berwirausaha diukur dengan merujuk pada penelitian Aulia Rahmi (2013) dan Artiandewi (2016) terdapat 3 indikator, antara lain perasaan tertarik untuk berwirausaha, karir berwirausaha, dan berniat untuk direalisakan di masa yang akan datang. 
Ahmad Sya Roni \& Sanaji. Pengaruh Efikasi Diri Berwirausaha terhadap Niat Berwirausaha Masyarakat Desa

\section{HASIL DAN PEMBAHASAN}

\section{Karakteristik Responden}

Karakteristik responden dalam penelitian ini dibagi menjadi lima bagian, yaitu berdasarkan gender, usia, pendidikan, pekerjaan, jenis bidang usaha tempat kerja, posisi pada perusahaan tempat kerja, jenis bidang usaha yang ingin direalisasikan. Berdasarkan gender sebanyak 67\% laki-laki dan 33\% perempuan. Berdasarkan usia sebanyak 27 responden (27\%) merupakan responden yang berusia antara 16-24 tahun, sebanyak 43 responden (43\%) berusia 25-32 tahun, pada rentang usia 33-41 tahun sebanyak 18 responden (18\%) dan pada usia diatas 42 tahun sebanyak 12 responden (12\%). Berikutnya berdasarkan kategori pendidikan menunjukkan bahwa dari 100 responden yang diteliti sebanyak 8 responden (8\%) adalah lulusan SMP, 72 responden (72\%) adalah lulusan SMA, 18 responden (18\%) adalah lulusan Perguruan Tinggi dan ada 2 reponden termasuk dalam kategori lain-lain dengan asumsi tidak mengenyam bangku pendidikan ataupun hanya lulusan sekolah dasar. Dalam kategori pekerjaan responden, sebanyak 7 responden (7\%) adalah PNS, 57 responden $(57 \%)$ adalah pegawai swasta, responden (4\%) adalah TNI/Polri, 32 reponden (32\%) masuk kategori lainnya dengan asumsi bekerja sebagai ibu rumah tangga maupun pelajar/mahasiswa. Pada kategori jenis usaha tempat kerja sebanyak 9 responden $(9 \%)$ bekerja pada bidang usaha makanan/minuman, sebanyak 30 responden bekerja pada perusahaan yang bergerak di bidang fashion seperti produksi tas, konveksi dan lain-lain, sebanyak 4 responden bekerja di bidang otomotif, pada perusahaan retail terdapat sebanyak 14 responden, dan kategori lainnya memiliki jumlah responden sebanyak 43 (43\%). Selanjutnya pada kategori job desk sebanyak 34 responden (34\%) bekerja pada bagian produksi, sebanyak 9 responden (9\%) bekerja sebagai marketing, sebanyak 19 responden (19\% ) bekerja sebagai admin dan sebanyak 38 responden (38\%) menjawab lainnya. Jenis usaha yang paling banyak diinginkan responden pada penelitian ini adalah usaha retail dengan 36 responden, yang kedua jenis usaha fashion dengan 24 reponden, ketiga makanan/ minuman dengan 19 responden, selanjutnya jenis usaha lain dengan 13 responden dan otomotif dengan 8 responden.

\section{Uji Validitas, Reliabilitas, dan Uji Asumsi Klasik}

Uji validitas dilakukan atas dasar masing-masing item pernyataan dengan menggunakan faktor analisis terhadap setiap item pernyataan. Suatu pernyataan dikatakan valid jika nilai r-hitung yang merupakan nilai Correlated Item - Total Correlation > r-tabel $(0,361)$. Jadi apabila suatu pernyataan memiliki nilai r-hitung di bawah 0,361 maka dikatakan tidak valid Ghozali (2016:52). Uji ini dipilih untuk mengetahui kelayakan instrumen penelitian terhadap masyarakat desa Kedensari, kecamatan Tanggulangin Sidoarjo dan juga menggunakan uji asumsi klasik untuk menganalisis data.

Tabel 1 menunjukkan bahwa semua item pernyataan dinayatakan valid karena nilai Corrected Item Total Correlation di atas 0,361 sehingga item pernyataan tersebut dapat digunakan sebagai alat ukur pengaruh efikasi diri berwirausaha terhadap niat berwirausaha.

Pada tabel 2, besarnya nilai Cronbach's Alpha untuk pengaruh experiential marketing, kepuasan konsumen dan niat loyalitas konsumen lebih besar dari 0,60. Sehingga disimpulkan bahwa pernyataanpernyataan pada instrumen penelitian (angket) reliabel dan dapat digunakan sebagai alat ukur pengaruh efikasi diri berwirausaha terhadap niat berwirausaha.

\section{Analisis Kelayakan Model dan Pengujian Hipotesis}

Pernyataan pada instrumen penelitian (angket) valid dan dan reliabel karena nilai $r$ hitung (Corrected Item total Correlation) > $\mathrm{r}$ tabel, maka dapat digunakan sebagai alat ukur pengaruh efikasi diri berwirausaha terhadap niat berwirausaha masyrakat desa Kedensari, kecamatan Tanggulangin, kabupaten Sidoarjo. Model yang digunakan adalah analisis regresi linear sederhana. Model yang baik harus memenuhi asumsi normalitas dan terbebas dari asumsi klasik. Adapun hasil pengujian asumsi klasik dalam penelitian ini adalah uji normalitas pada analisis grafik berdistribusi normal, sedangkan pada analisis statistik nilai signifikansi uji kolmogorov smirnov lebih besar dari 0,05 yaitu 0,064 sehingga data dapat diolah menggunakan regresi linear berganda. Pada uji multikolineritas nilai VIF dari kedua variabel kurang dari 10 yaitu 1,000 sehingga model regresi linier berganda terbebas dari masalah multikolinieritas. Untuk uji heterodkedastisitas nilai signifikasi t kedua variabel bebas yang 
dihasilkan dari uji non parametic lebih besar dari 0,05 yaitu 0,564 sehingga model regresi linier sederhana terbebas dari masalah heteroskedastisitas. Setelah data terbebas dari asumsi-asumsi klasik, kemudian dilakukan analisis regresi linear berganda. Hasil analisis regresi linier berganda dapat dilihat di tabel 3. Berdasarkan tabel 3, diperoleh model persamaan regresi linier berganda pada rumus (1).

$Y=18,093+0,144 X$

Tabel 1.

HASIL UJI VALIDITAS

\begin{tabular}{lccc}
\hline \multicolumn{1}{c}{ Variabel } & Corrected Item - Total Correlation & r Tabel & Keterangan \\
\hline Efikasi Diri Berwirausaha $(\mathrm{X})$ & & & \\
X1.1 & 0,920 & & Valid \\
X1.2 & 0,799 & Valid \\
X1.3 & 0,783 & Valid \\
X2.1 & 0,625 & Valid \\
X2.2 & 0,690 & Valid \\
X2.3 & 0,793 & Valid \\
X3.1 & 0,661 & Valid \\
X3.2 & 0,608 & Valid \\
X4.1 & 0,449 & Valid \\
X4.2 & 0,556 & Valid \\
X4.3 & 0,860 & Valid \\
X4.4 & 0,824 & & Valid \\
X4.5 & 0,638 & & Valid \\
X4.6 & 0,643 & & Valid \\
X5.1 & 0,706 & Valid \\
X5.2 & 0,860 & Valid \\
X5.3 & 0,344 & Valid \\
Niat Berwirausaha (Y) & & \\
Y1.1 & 0,627 & & Valid \\
Y1.2 & 0,695 & Valid \\
Y2.1 & 0,569 & Valid \\
Y2.2 & 0,648 & Valid \\
Y3.1 & 0,744 & Valid \\
Y3.2 & 0,500 & Valid \\
\hline S
\end{tabular}

Sumber: Data diolah

Tabel 2.

HASIL UJI RELIABILITAS

\begin{tabular}{lccc}
\hline \multicolumn{1}{c}{ Variabel } & Cronbach Alpha & Nilai Kritis & Keterangan \\
\hline Efikasi Diri Berwirausaha & 0,913 & 0,60 & Reliabel \\
Niat Berwirausaha & 0,616 & 0,60 & Reliabel \\
\hline
\end{tabular}

Sumber: Data diolah

Dari persamaan regresi (1), nilai konstanta sebesar 18,093 menyatakan jika responden tidak mengetahui tentang efikasi diri berwirausaha, maka niat berwirausaha masyarakat desa Kedensari akan tetap muncul. Nilai koefisien regresi variabel efikasi diri berwirausaha sebesar 0,144 menyatakan bahwa adanya hubungan yang positif antara efikasi diri berwirausaha terhadap niat berwirausaha masyarakat desa Kedensari. Artinya, jika masyarakat memiliki kepercayaan diri berwirausaha (efikasi diri berwirausaha), maka akan muncul niat berwirausaha. Nilai koefisien determinasi yang disesuaikan (Adjusted $\mathrm{R}$ square) yang dihasilkan sebesar 0,313. Artinya efikasi diri berwirausaha berpengaruh terhadap niat berwirausaha masyarakat desa Kedensari sebesar 0,313 atau 31,3\%\%. Sedangkan kontribusi pengaruh sebesar $68,7 \%$, disebabkan oleh faktor-faktor lain. 
Ahmad Sya Roni \& Sanaji. Pengaruh Efikasi Diri Berwirausaha terhadap Niat Berwirausaha Masyarakat Desa

Uji t dilakukan untuk menguji pengaruh variabel-variabel bebas terhadap variabel terikat secara parsial (individual). Hasil dari uji t sebagai berikut. Hasil hipotesis 1: Hasil uji t pada penelitian ini adalah nilai $t_{\text {hitung }}$ sebesar 6,677 lebih besar daripada $t_{\text {tabel }}$ sebesar 1,987 dengan nilai signifikansi 0,000 lebih kecil dibandingkan 0,05 sehingga diputuskan menolak $\mathrm{H}_{0}$ dan menerima $\mathrm{H}_{1}$. Disimpulkan bahwa semakin tinggi pengaruh efikasi diri berwirausaha terhadap niat berwirausaha masyarakat desa Kedensari, kecamatan Tanggulangin, kabupaten Sidoarjo. Uji F digunakan untuk menguji pengaruh variabelvariabel bebas terhadap variabel terikat secara bersama-sama (simultan). Hasil dari uji $\mathrm{F}$ sebagai berikut. Hasil hipotesis 2: Hasil uji $\mathrm{F}$ pada penelitian ini adalah dilihat dari nilai $\mathrm{F}_{\text {hitung }}$ sebesar 44,578 dengan probabilitas 0,000 . Karena probabilitas lebih kecil dari 0,05 maka model regresi dapat digunakan untuk mengetahui pengaruh efikasi diri berwirausaha terhadap niat berwirausaha masyarakat desa Kedensari, kecamatan Tanggulangin, kabupaten Sidoarjo.

Tabel 3.

RINGKASAN HASIL ANALISIS REGRESI LINEAR SEDERHANA

\begin{tabular}{ccccc}
\hline Model & B & thitung $_{\text { }}$ & Sig. t & r parsial \\
\hline Konstanta & 18,093 & 14,416 & 0,000 & \\
Efikasi Diri & 0,144 & 6,677 & 0,000 & 0,559 \\
R square & $=0,313$ & & & \\
Adj R square & $=0,306$ & & & \\
F hitung & $=44,578$ & & & \\
Sig. F & $=0,000$ & & & \\
\hline Sumber: Output SPSS 23 & & &
\end{tabular}

Efikasi diri berwirausaha berpengaruh positif dan signifikan terhadap niat berwirausaha. Hal tersebut dapat dibuktikan dengan nilai signifikansi lebih kecil dari nilai yang ditentukan. Dan korelasi dari variabel efikasi diri berwirausah terhadap niat berwirausaha didapat dari nilai $\mathrm{R}$ yang ada pada hasil pengolahan data yang dilakukan sebesar $31.3 \%$. Hal ini menunjukkan korelasi antara efikasi diri berwirausaha terhadap niat berwirausaha mayarakat desa, Kedensari, kecamatan Tanggulangin, kabupaten Sidoarjo sebesar 31.3\% dan sisanya yaitu 68.7\% dipengaruhi oleh variabel lain.

\section{Pengaruh Efikasi Diri Berwirausah terhadap Niat Berwirausaha}

Berdasarkan pengujian penelitian ini diperoleh hasil bahwa efikasi diri berwirausaha berpengaruh signifikan terhadap niat berwirausaha. Maka dapat dijelaskan bahwa semakin tinggi efikasi diri berwirausaha semakin meningkat pula niat berwirausaha mayarakat desa, Kedensari, kecamatan Tanggulangin, kabupaten Sidoarjo. Ada banyak faktor yang memengaruhi efikasi diri berwirausaha, salah satunya yaitu marshaling yang berarti kepercayaan diri seseorang untuk menyusun atau mengatur suatu organisasi dengan melibatkan orang lain untuk mendiskusikan masalah yang terjadi, terbukti dengan jawaban responden mengenai indikator marshaling yang memiliki skor rata-rata tertinggi sebesar 3,575. Apabila marshaling (kepercayaan diri menyelesaikan masalah yang terjadi) yang dimiliki masyarakat kurang maka mampu mengurangi kepercayaan diri mereka untuk berwirausaha dan mereka lebih memilih menjadi karyawan. Tetapi marshaling mayarakat desa, Kedensari, kecamatan Tanggulangin, kabupaten Sidoarjo dinilai baik dan akan berdampak pada meningkatnya kepercayaan diri untuk berwirausaha. Implementing-people, yaitu kemampuan yang dimiliki seseorang untuk mengatur seorang atau sekelompok orang di dalam sebuah organisasi juga mampu memengaruhi efikasi diri berwirausaha. Terbukti bahwa indikator implementing-people pada variabel ini juga memiliki skor rata-rata yang tinggi pula, yaitu sebesar 3,388. Hasil diatas sesuai dengan penelitian yang dilakukan oleh McGee et. al. (2009) yang menjelaskan marshaling dan implementing-people memberikan kontribusi terhadap niat berwirausaha mayarakat desa, Kedensari, Kecamatan Tanggulangin, Kabupaten Sidoarjo secara positif dan signifikan.

Masyarakat desa, Kedensari, kecamatan Tanggulangin, kabupaten Sidoarjo dapat dikatakan sebagian besar memiliki efikasi diri berwirausaha dikarenakan dalam kehidupan sehari-hari sejak kecil berada di lingkungan UMKM yang secara tidak langsung ikut berperan dalam kegiatan di dalamnya, sehingga dari pengalaman tersebut muncul jiwa kewirausahaan dan banyak masyarakat yang memiliki keinginan 
untuk berwirausaha. Dari hasil wawancara ke beberapa responden, dari banyak responden yang sudah memiliki tabungan untuk merealisasikan niatnya untuk memiliki usaha sendiri sehingga dapat disimpulkan niat berwirausaha mayarakat desa, Kedensari, kecamatan Tanggulangin, kabupaten Sidoarjo dinilai cukup tinggi.

Efikasi diri berwirausaha merupakan suatu konstruk yang mengukur kepercayaan individu pada kemampuan yang dimiliki dalam berkecimpung dalam dunia kewirausahaan. Efikasi diri berwirausaha (entrepreneurial self efficacy) masyarakat dapat ditingkatkan dengan berbagai cara salah satunya dengan dimensi ESE, yang pertama searching, artinya pencarian sebuah gagasan dan informasi untuk memulai kegiatan usaha. Kedua adalah planning yaitu merencanakan atau menentukan visi, misi dan tujuan, strategi, kebijakan, prosedur, aturan, program dan anggaran yang diperlukan untuk menjalankan suatu usaha. Ketiga yakni marshaling, yaitu kepercayaan diri untuk menyusun atau mengatur suatu organisasi dengan melibatkan orang lain untuk mendiskusikan masalah yang terjadi pada sebuah organisasi/perusahaan. Keempat implementing-people, yaitu kemampuan untuk mengatur individu atau sekelompok orang di dalam sebuah organisasi dan kelima Implementing-financial, yaitu kemampuan dalam mengelola keuangan pribadi maupun organisasi. Implikasi dari penelitian ini adalah peningkatan efikasi diri efikasi diri berwirausaha (entrepreneurial self efficacy) akan menciptakan niat berwirausaha pada masyarakat desa Kedensari, kecamatan Tanggulangin, kabupaten Sidoarjo. Di samping itu, banyak faktor-faktor lain yang memengaruhi niat berwirausaha masyrakat. Oleh karena itu sekiranya perlu diadakan penelitian lebih lanjut untuk meneliti faktor-faktor lain yang memengaruhi niat berwirausaha. Dari hasil uji regresi linear sederhana menunjukkan bahwa masyarakat desa Kedensari memiliki niat berwirausaha yang cukup tinggi namun ada beberapa faktor lain yang memengaruhi, salah satunya yaitu pengalaman yang dimiliki masyarakatnya, karena sejak dari kecil pemuda desa Kedensari, Tanggulangin sudah terbiasa melihat orang tua ataupun orang disekitarnya memproduksi tas dari mulai bahan baku hingga menjadi barang yang layak jual. Jadi dapat dikatakan sebagian besar masyarakat yang hidup di area sentra industri kerjajinan kulit Tanggulangin mulai dari bayi sudah mendengar suara mesin jahit, mereka yang masih berada di bangku sekolah dasar, sepulang dari sekolah turut membantu orang tua masing-masing dalam proses pengolahan bahan baku hingga menjadi produk, lalu saat memasuki SMP mereka sudah bisa menjahit yang mana proses tersebut adalah proses yang cukup sulit untuk dikerjakan. Jadi dapat disimpulkan sebagian besar masyarakat desa Kedensari, kecamatan Tanggulangin memiliki keahlian dan keterampilan untuk menciptakan suatu produk yang memiliki nilai jual.

\section{KESIMPULAN}

Sebagian besar masyarakat dapat dikatakan memiliki kepercayaan diri untuk berwirausaha (efikasi diri berwirausaha) dikarenakan dalam kehidupan sehari-hari sejak kecil berada di lingkungan UMKM yang secara tidak langsung ikut berperan dalam kegiatan di dalamnya, dari pengalaman tersebut muncul jiwa kewirausahaan dan banyak masyarakat yang memiliki keinginan untuk berwirausaha dan responden (dapat mewakili masyarakat) beberapa ada yang sudah memiliki tabungan untuk merealisasikan niatnya untuk memiliki usaha sendiri, maka simpulan dalam penelitian ini yaitu niat berwirausaha mayarakat desa, Kedensari, kecamatan Tanggulangin, kabupaten Sidoarjo dinilai cukup tinggi. Variabel efikasi diri berwirausaha terbukti berpengaruh secara positif dan signifikan terhadap niat berwirausaha masyarakat desa Kedensari, kecamatan Tanggulangin, Kabupaten Sidoarjo.

Penelitian ini telah diusahakan dan dilaksanakan sesuai dengan prosedur ilmiah, namun demikian masih memiliki keterbatasan yaitu sebagai berikut. Faktor-faktor yang memengaruhi niat berwirausaha dalam penelitian ini hanya terdapat satu variabel, yaitu efikasi diri berwirausaha, sedangkan masih terdapat banyak faktor lain yang memengaruhi niat berwirausaha. Penelitian tentang efikasi diri berwirausaha jumlahnya tergolong kecil di Indonesia sehingga literasi yang diperlukan kurang. Adanya keterbatasan penelitian dengan menggunakan kuesioner yaitu terkadang jawaban yang diberikan oleh responden tidak menunjukkan keadaan sesungguhnya. Penelitian selanjutnya dapat melibatkan variabel pengalaman kerja, pengaruh latar belakang orang tua atau variabel lain yang berkaitan. 
Ahmad Sya Roni \& Sanaji. Pengaruh Efikasi Diri Berwirausaha terhadap Niat Berwirausaha Masyarakat Desa

Untuk menumbuhkan niat berwirausaha masyarakat khususnya dikalangan generasi muda dengan harapan agar tercipta wirausahawan-wirausahawan muda yang intelek, maka disarankan melakukan upaya peningkatan pengetahuan kewirausahaan seharusnya. Selain itu, peningkatan kepercayaan individu bahwa mereka mampu memulai dan menjalankan usaha sebagai cerminan efikasi diri berwirausaha juga perlu ditingkatkan dengan melalui berbagai program pengembangan.

\section{DAFTAR PUSTAKA}

Ajzen, I. 2008. Attitudes and Attitude Change. Psychology Press: WD Crano eds.

Alma, B. 2013. Kewirausahaan Untuk Mahasiswa Dan Umum. Bandung: Alfabeta.

Artiandewi, A. 2016. Pengaruh Efikasi Diri Berwirausaha Dan Pendidikan Kewirausahaan Terhadap Intensi Berwirausaha Mahasiswa Pendidikan Administrasi Perkantoran Universitas Negeri Yogyakarta. Jurnal Pendidikan Administrasi Perkantoran Universitas Negeri Yogyakarta (Vol5, no.4).

Azwar, Saifuddin. 1997. Metode Penelitian. Yogyakarta : Pustaka Pelajar.

Bandura, A. 1997. Self Efficacy - The Exercise of Control. Fifth Printing, 2002. New York: W.H. Freeman \& Company.

Bird, Barbara. 1988. Implementing Entrepreneurial Ideas: The Case For Intentions. Academy of Management Review, 13, 442-54.

Boyd, N. G., \& Vozikis, G. S. (1994). The influence of self-efficacy on the development of entrepreneurial intentions and actions.

Dede Rahmat Hidayat. 2011. Psikologi Kepribadian dalam Konseling. Jakarta : Indeks

Djaali. 2013. Psikologi Pendidikan. Jakarta : PT. Bumi Aksara.

Ekonome.id. 2016. Wirausaha Pengertian Sikap Mental dan Prospek pada Masa yang Akan Datang. (https://ekonome.id/2016/10/wira-usaha-pengertian-sikap-mental-dan-prospek-pada-masayang-akan-datang/, di akses pada 9 Januari 2019).

Firmansyah B. 2013. Keterkaitan Pengalaman Kewirausahaan, Sikap, Norma Subyektif, Kontrol Perilaku terhadap Niat untuk menjadi Wirausahawan (Studi pada perajin batik di kota surakarta, kabupaten sragen dan kabupaten karanganyar). Riset Manajemen \& Akuntansi Volume 4 Nomor 7 Edisi Mei 2013.

Gegecar.co.id. 2013. Pentingnya Kewirausahaan. (http://gegecar.blogspot.co.id/2013/06/pentingnyakewirausahaan-untuk.html, di akses pada 5 Maret 2017).

Ghozali, Imam. 2016. Aplikasi Analisis Multivariete dengan Program IBM SPSS 21. Semarang: Badan Penerbit Universitas Diponegoro

Hartarto. 2018. Jumlah Pengusaha Indonesia Masih Tertinggal Dari Singapura. (https://m.wartaekonomi.co.id/berita204928/jumlah-pengusaha-indonesia-masih-tertinggaldari-singapura.html, di akses pada 9 Januari 2019).

Hisrich, Robert D., Michael P. Peters, dan Dean A. Shepherd. 2008. Entrepreneurship Kewirausahaan. Jakarta: Salemba Empat. 
Indarti, Nurul \& Stein, Kristiansen. 2003. "Determinants of Entrepreneurial Intention: The Case of Norwegian Student", Gadjah Mada International Journal of Business. (Vol. 5, No. 1).

Indarti, Nurul dan Rostiani, Rokhima. 2008. "Intensi Kewirausahaan Mahasiswa: Studi Perbandingan Antara Indonesia, Jepang dan Norwegia.” Jurnal Ekonomika dan Bisnis Indonesia. (Vol. 23, No. 4).

Indonesia-investments.com. 2016. Pengangguran di Indonesia. (http://www.indonesiainvestments.com/id/keuangan/angka-ekonomi-makro/pengangguran/item255, di akses pada 13 Desember 2018).

José, L. M. Campo. 2011. Analysis of the influence of self-efficacy on entrepreneurial intentions. International Journal Julio. Vol. 9, No. 2.

Kartika Sandy, Ayu. 2017. Sidoarjo Kota UKM Indonesia. (https://ayukartikasandy.wordpress.com/2017/02/21/sidoarjo-kota-ukm-indonesia/, di akses pada 15 April 2019).

Kasmir. 2011. Kewirausahaan. Edisi Revisi. Jakarta: PT. Raja Grafindo Persada.

King, Laura A. 2010. Psikologi Umum. (Alih Bahasa: Brian Marwendys). Jakarta: Salemba Humanika.

Kusumaningrum, Dina. 2018. Kekuatan Ekonomi Indonesia Berada di Sektor UKM. (https://www.wartaekonomi.co.id/read167266/60-kekuatan-ekonomi-indonesia-berada-disektor-ukm.html, di akses pada 29 Mei 2020).

Lambing, P. A., \& Kuehl. C. R. 2007. Entrepreneurship. 4th edition. Upper Saddle River: Prentice Hall.

Luthans, F. 2008.”Perilaku Organisasi”. Jogjakarta: Penerbit Andi.

McGee, Jeffrey E. et al. 2009. Entrepreneurial Self-Efficacy: Refining TheMeasure. Baylor University. DOI: $10.1111 / \mathrm{j} .1540-6520.2009 .00304 . \mathrm{x}$

Mueller, S. L and Goic, S. (2003). East-West differences in entrepreneurial self-efficacy: Implications for entrepreneurship education in transition economies. International Journal of Entrepreneurship Education, Vol.1 Issues 4.

Sari, Tita Novita. 2018. Wirausaha Mengurangi Pengangguran dan Menambah Kesempatan Kerja. (https://www.slideshare.net/TitaNovitaSari/wirausaha-mengurangi-pengangguran-danmenambah-kesempatan-kerja/, di akses pada 14 April 2019).

Pemerintah Desa Kedensari. 2018. Profil Desa Kedensari tahun 2018.

Penyusun, T. 2014. Pedoman penulisan Skripsi Universitas Negeri Surabaya. Surabaya: UNESA Press.

Republika.co.id. 2016. UMKM Sukses Mengurangi Pengangguran. (https://www.republika.co.id/berita/koran/ekonomi-koran/16/11/22/oh1a8b4-umkm-suksesmengurangi-pengangguran/, di akses pada 15 April 2019).

Suryaman, Maman. 2006. Minat Berwirausaha Pada Mahasiswa Pendidikan Teknik Elektro Fakultas Teknik Universitas Negeri Semarang, Skripsi, Fakultas Teknik - Universitas Negeri Semarang

Santoso. 1993. Kompetisi dan Kepercayaan Diri Remaja. Yogyakarta: Liberty

Slameto. 1994. Belajar Dan Faktor Yang Memengaruhinya. Jakarta: Rineka Cipta 
Ahmad Sya Roni \& Sanaji. Pengaruh Efikasi Diri Berwirausaha terhadap Niat Berwirausaha Masyarakat Desa

Sugiyono. 2010. Metode Penelitian Bisnis. Bandung: ALFABETA.

Suryana. 2013.Kewirausahaan Kiat dan Proses Menuju Sukses. Jakarta: SALEMBA EMPAT.

Tempo.co. 2017. Minat Wirausaha di Indonesia Sangat Rendah. (https://m.tempo.co/read/news/2016/03/08/087751831/minat-wirausaha-di-indonesia-sangatrendah, di akses pada 17 Januari 2017).

Ully Rachmawati. 2011. "Hubungan Internal Locus of Control dan Dukungan Sosial dengan Intensi Berwirausaha pada siswa SMA."Skripsi tidak diterbitkan. UGM.

Shaleh, A. R. \& Wahab, M. A. 2005. Psikologi Suatu Pengantar: Dalam Perspektif Islam. Jakarta: Prenada Media.

Winarno, W. W. 2011. Analisis Ekonometrika dan Statistika dengan Eviews, Edisi Ketiga. Yogyakarta : Unit Penerbit dan Percetakan (UPP STIM YKPN).

Yunita, W. A. 2014. Pengaruh Pendidikan Kewirausahaan Terhadap Motivasi Berwirausaha Dan Keterampilan Berwirausaha Mahasiswa Pendidikan Ekonomi Universitas Negeri Yogyakarta. Lumbung pustaka Universitas Negeri Yogyakarta.

Yuyus, Suryana \& Kartib Bayu. (2011). Kewirausahaan : Pendekatan Karakteristik Wirausahawan Sukses. Jakarta: Prenada Media Group.

Zimmerer, Thomas W. dan Norman Scarborough. 2008. Kewirausahaan dan Manajemen Usaha Kecil. Jakarta: Salemba Empat. 